\title{
EDUKASI PENCEGAHAN COVID-19 MELALUI MEDIA POSTER DAN SPANDUK PADA WARGA KELURAHAN PANJI KECAMATAN TENGGARONG
}

\author{
Rahmi Susanti, Tahsya Erika \\ Fakultas Kesehatan Masyarakat, Universitas Mulawarman \\ email: rahmi.susanti@,fkm.unmu.ac.id
}

\begin{abstract}
Indonesia is one of the countries with a fairly high number of Covid-19 virus cases. Covid-19 is a virus that attacks the respiratory system with mild symptoms such as cough, runny nose, sore throat, and fever. Covid-19 can spread through small droplets from the respiratory tract when coughing and sneezing. Covid-19 cases in East Kalimantan have increased every day based on data obtained from the Kutai Kartanegara District Health Office until December 17, 2020, there were 4,500 positive cases of Covid-19 recorded. One of the preventive efforts to prevent the spread of Covid-19 is by providing education through printed media such as posters and banners related to the dangers and prevention of Covid-19 as well as health information access. Destinationthe activities of distributing posters and installing banners are to provide knowledge and increase public awareness about the dangers and prevention methods so that people avoid Covid19 transmission. The method of implementing this activity is in the form of distributing posters directly to residents' homes and installing banners in the Gang Nidatul Khair RT area. 12 Panji Village, Tenggarong District, Kutai Kartanegara Regency on November 28, 2020 with a total of 15 posters and 1 banner about hazards and prevention. Covid-19 and access to health information. The result of this activitygetting a pretty good reception by the community as shown by the information conveyed can increase knowledge and increase public awareness about the dangers and importance of preventing Covid-19 and access to health information.
\end{abstract}

Keywords: Covid-19, Prevention, Health Information

\author{
ABSTRAK
}


Indonesia merupakan salah satu negara dengan jumlah kasus virus Covid-19 yang cukup tinggi. Covid-19 adalah virus yang menyerang system pernapasan dengan gejala ringan seperti batuk, pilek, sakit tenggorokan, dan demam. Covid-19 dapat menyebar melalui tetesan kecil (droplet) dari saluran pernapasan ketika batuk dan bersin. Kasus Covid-19 di Kalimantan Timur mengalami peningkatan setiap harinya berdasarkan data yang diperoleh dari Dinas Kesehatan Kabupaten Kutai Kartanegara hingga tanggal 17 Desember 2020 tercatat jumlah kasus positif Covid-19 sebanyak 4.500 kasus. Salah satu upaya preventif dalam mencegah penyebaran Covid-19 yaitu dengan melakukan edukasi melalui media cetak seperti poster dan spanduk terkait bahaya dan pencegahan Covid-19 serta askes informasi kesehatan. Tujuan kegiatan pembagian poster dan pemasangan spanduk adalah untuk memberikan pengetahuan dan meningkatkan kesadaran masyarakat tentang bahaya serta cara pencegahan agar masyarakat terhindar dari penularan Covid-19. Metode pelaksanaan kegiatan ini berupa tindakan pembagian poster secara langsung ke rumah warga dan pemasangan spanduk di wilayah Gang Nidatul Khair RT.12 Kelurahan Panji Kecamatan Tenggarong, Kabupaten Kutai kartanegara pada tanggal 28 November 2020 dengan jumlah poster sebanyak 15 lembar dan 1 spanduk tentang bahaya dan pencegahan Covid-19 serta akses informasi kesehatan. Hasil dari egiatan ini mendapatkan penerimaan yang cukup baik oleh masyarakat yang ditunjukan dengan adanya informasi yang disampaikan dapat menambah pengetahuan serta meningkatkan kesadaran masyarakat tentang bahaya dan pentingnya pencegahan Covid-19 serta akses informasi kesehatan.

Kata Kunci: Covid-19, pencegahan, informasi Kesehatan 


\section{A. PENDAHULUAN}

Dunia saat ini sedang dilanda pandemi dari sebuah virus yang dikenal dengan sebutan coronavirus. Coronavirus merupakan keluarga besar virus yang menyebabkan penyakit pada manusia dan hewan. Pada manusia biasanya menyebabkan penyakit infeksi saluran pernapasan, flu biasa hingga penyakit yang serius seperti Middle East Respiratory Syndrome (MERS) dan Severe Acute Respiratory Syndrome (SARS). Coronavirus jenis baru yang ditemukan pada manusia sejak kejadian luar biasa muncul di Wuhan Cina, pada Desember 2019, kemudian diberi nama Severe Acute Respiratory Syndrome Coronavirus 2 (SARSCOV2), dan menyebabkan penyakit Coronavirus Disease-2019 atau Covid-19 (WHO, 2020). Covid-19 memiliki gejala ringan seperti batuk, pilek, sakit tenggorokan, dan demam. Penderita dengan gejala yang berat bisa mengalami demam tinggi, batuk berdahak bahkan berdarah, sesak napas, serta nyeri dada. Masa inkubasi Covid-19 berkisar dari 1 hingga 14 hari. Covid-19 dapat menyebar melalui tetesan kecil (droplet) dari saluran pernapasan ketika batuk atau bersin, dan bisa juga terinfeksi melalui droplet yang berasal dari penderita Covid-19 (Kementrian Kesehatan, 2020).

Indonesia merupakan salah satu negara dengan jumlah kasus terkonfirmasi Covid-19 yang cukup tinggi, yakni hingga tanggal 17 Desember tercatat sebanyak kasus 643.508 (Kompas, 2020). Kalimantan Timur merupakan provinsi dengan jumlah kasus yang peningkatannya sangat pesat. Data kasus Covid-19 pada tanggal 17 Desember khususnya di Kabupaten Kutai Kartanegara menunjukan jumlah kasus terkonfirmasi sebanyak 4.500 kasus, hal ini menunjukan bahwa kabupaten Kutai Kartanegara menjadi urutan ke tiga tertinggi setelah kota Balikpapan dan Samarinda (Dinas Kesehatan Kabupaten Kutai Kartanegara, 2020). 
Tindakan pencegahan dan mitigasi merupakan kunci penerapan di pelayanan kesehatan dan masyarakat. Langkah-langkah pencegahan yang paling efektif dalam mencegah penyebaran Covid-19 di masyarakat yaitu seperti mencuci tangan menggunakan sabun, menggunakan hand sanitaizer, menghindari menyentuh mata, hidung dan mulut, menerapkan etika batuk dan bersin, menggunakan masker serta menjaga jarak (minimal $1 \mathrm{~m}$ ) dari orang yang mengalami gejala gangguan pernapasan (Kementrian Kesehatan, 2020). Berbagai upaya preventif sudah dilakukan, hal tersebut didukung oleh kontribusi media cetak dan media sosial sebagai edukasi masyarakat tentang Covid-19. Informasi kesehatan dapat dikases melalui media cetak dan media sosial khususnya terkait bahaya dan pencegahan Covid-19. Penggunaan media cetak seperti poster dan spanduk dapat memengaruhi perilaku individu di lingkungan masyarakat sehingga diperlukan adanya upaya untuk mempertahankan kebiasaan atas perubahan perilaku terhadap kesehatan. Meskipun banyak faktor yang mempengaruhi perilaku yang berhubungan dengan kesehatan, kesadaran masyarakat terhadap risiko dalam melakukan perubahan perilaku merupakan unsur utama dalam meningkatkan kesehatan individu serta status kesehatan masyarakat agar terhindar dari Covid-19.

Berdasarkan hasil survey yang telah dilakukan pada wilayah Gang Nidatul Khair RT.12 Kelurahan panji ditemukan permasalahan terkait Covid-19 seperti masih terdapat masyarakat yang menyatakan bahwa Covid-19 adalah penyakit yang tidak berbahaya dan sama seperti flu biasa, tidak menggunakan masker pada saat keluar rumah serta tidak ada poster atau spanduk pencegahan Covid-19. Oleh karena itu, maka perlu melakukan kegiatan pengabdian masyarakat dengan cara pembagian 
poster dan pemasangan spanduk sebagai media edukasi terkait bahaya dan pencegahan Covid-19 serta akses informasi kesehatan.

\section{B. PELAKSANAAN DAN METODE}

Metode yang digunakan dalam kegiatan Pengalaman Belajar Lapangan (PBL) ini meliputi pembagian poster dan pemasangan spanduk. Kegiatan Pengalaman Belajar Lapangan (PBL) diawali dengan melakukan kegiatan analisis situasi dengan metode observasi atau pengamatan secara langsung yang diperkuat dengan survei online yang telah dilakukan. Kegiatan analisis situasi dimulai dengan melakukan survey lokasi dan pengurusan perizinan kegiatan kepada RT.12 serta menyepakati waktu pelaksanaan kegiatan. Adapun sasaran pada kegiatan ini adalah masyarakat yang berdomisili di Gang Nidatul Khair RT.12 Kelurahan Panji. Kegiatan edukasi terkait bahaya dan pencegahan Covid-19 serta akses informasi kesehatan dilakukan dengan berupa tindakan dalam bentuk pembagian poster dan pemasangan spanduk diwilayah Gang Nidatul Khair RT.12 Kelurahan Panji. Kegiatan pembagian poster dilakukan dengan cara mendatangi langsung rumahrumah warga dengan memberikan informasi terkait bahaya dan pencegahan Covid-19 serta meminta izin untuk dilakukan penempelan poster. Kegiatan pemasangan spanduk dilakukan di tempat yang strategis seperti pada musholla yang berada diwilayah Gang Nidatul Khair RT.12 Kelurahan Panji. Kegiatan Pengalaman Belajar Lapangan (PBL) dilakukan di wilayah Gang Nidatul Khair RT.12 Kelurahan Panji Kecamatan Tenggarong, Kabupaten Kutai Kartanegara pada tanggal 28 November 2020. 


\section{HASIL DAN PEMBAHASAN}

Kegiatan Pengalaman Belajar Lapangan (PBL) dilaksanakan selama satu hari yaitu tanggal 28 November 2020 yang berlokasi di wilayah Gang Nidatul Khair RT.12 Kelurahan Panji, Kecamatan Tenggarong, Kabupaten Kutai Kartanegara. Kegiatan ini diawali dengan melakukan kegiatan analisis situasi dengan metode observasi atau pengamatan secara langsung yang diperkuat dengan survei online yang telah dilakukan. Berdasarkan hasil survey online yang telah dilakukan terkait tingkat pengetahuan masyarakat yang ada di wilayah RT.12 diketasebanyak 40\% masyarakat menyatakan bahwa Covid-19 adalah penyakit yang tidak berbahaya dan sama seperti flu biasa. Selain itu berdasarkan hasil observasi atau pengamatan secara langsung masih terdapat masyarakat yang tidak mematuhi protocol kesehatan seperti tidak menggunakan masker pada saat keluar rumah serta belum terdapat media informasi berupa poster dan spanduk terkait upaya pencegahan penyebaran Covid-19.

Pada tahap perencanaan kegiatan, diawali dengan melakukan diskusi dengan dosen pembimbing untuk mengadakan pengabdian masyarakat yang diperlukan di wilayah Gang Nidatul Khair RT.12 Kelurahan Panji pada masa pandemic Covid-19. Langkah selanjutnya yaitu melakukan pengurusan perizinan kepada RT.12 serta menyepakati waktu pelaksanaan kegiatan. Setelah itu dilakukan pembuatan desain poster dan spanduk yang berisi informasi mengenai bahaya dan pencegahan Covid-19 serta askes informasi kesehatan. Kemudian dilakukan pencetakan poster dan spanduk sebanyak 15 lembar poster dan 1 spanduk. Pembagian poster dan pemasangan spanduk yang dilakukan di wilayah Gang Nidatul Khair RT.12 Kelurahan Panji. Pembagian poster dan pemasangan spanduk bertujuan untuk memberikan edukasi 
terkait bahaya dan pencegahan Covid-19 serta akses informasi kesehatan.

Kegiatan ini merupakan penyampaian informasi mengenai bahaya dan pencegahan serta akses informasi kesehatan melalui pembagian poster dan pemasangan spanduk. Poster terdistribusi kepada 15 orang yang berada di wilayah Gang Nidatul Khair RT.12. Kelurahan Panji. Pendistribusiannya adalah dengan membagikan secara langsung ke rumah warga dengan memberikan informasi terkait bahaya dan pencegahan Covid-19 serta meminta izin untuk dilakukan penempelan poster. Poster ditempel pada dinding rumah warga serta pada tempattempat yang strategis seperti pada papan informasi yang ada di depan musholla Gang Nidaul Khair RT.12 Kelurahan Panji. Kegiatan pemasangan spanduk dilakukan di tempat yang strategis seperti pada musholla yang berada diwilayah Gang Nidatul Khair RT.12 Kelurahan Panji.

Kegiatan pembagian poster dan pemasangan spanduk di wilayah Gang Nidatul Khair RT.12 Kelurahan Panji berjalan dengan lancar dan tanpa ada hambatan. Peluang dari kegiatan pembagian poster yaitu mendapatkan penerimaan yang cukup baik oleh masyarakat hal ini dibuktikan dari hasil pre-test dan post-test yang dilakukan pada saat sebelum dan sesudah pemberian edukasi mengenai bahaya dan pencegahan Covid-19 serta akses informasi kesehatan. Sebelum dilakukan pemberian edukasi, berdasarkan hasil pre-test yang telah dilakukan diketahui masih terdapat masyarakat yang tidak mengetahui secara pasti tanda dan gejala Covid-19 serta tidak mengetahui media yang digunakan untuk mengakses informasi kesehatan seperti hotline Covid-19 Kabupaten Kutai Kartanegara. Setelah dilakukannya pemberian edukasi, berdasarkan hasil post-test yang telah dilakukan 
terjadi peningkatan pengetahuan masyarakat mengenai tanda, gejala, bahaya dan pencegahan Covid-19 serta media yang dapat digunakan masyarakat untuk mengakses informasi kesehatan. Berdasarkan informasi yang telah disampaikan, diharapkan dapat menambah pengetahuan serta meningkatkan kesadaran masyarakat tentang bahaya dan pentingnya pencegahan Covid-19 serta akses informasi kesehatan.

\section{Gambar 1.}

Pembagian Poster Kepada Masyarakat Wilayah Gang Nidatul Khair RT.12 Kelurahan Panji
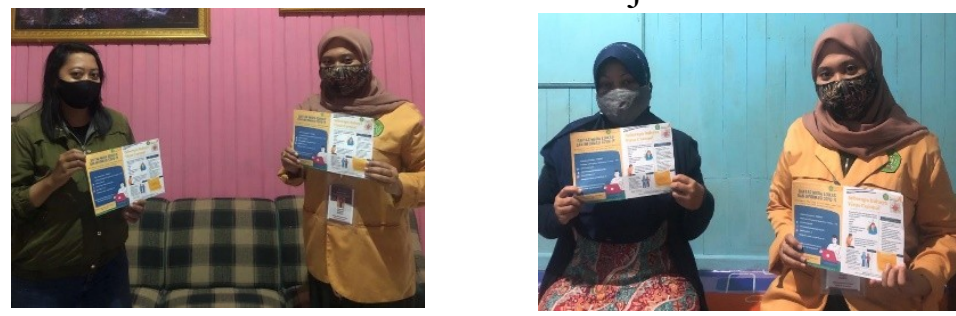

Gambar 2.

Penempelan Poster dan Pemasangan Spanduk di Wilayah Gang Nidatul Khair RT.12 Kelurahan Panji
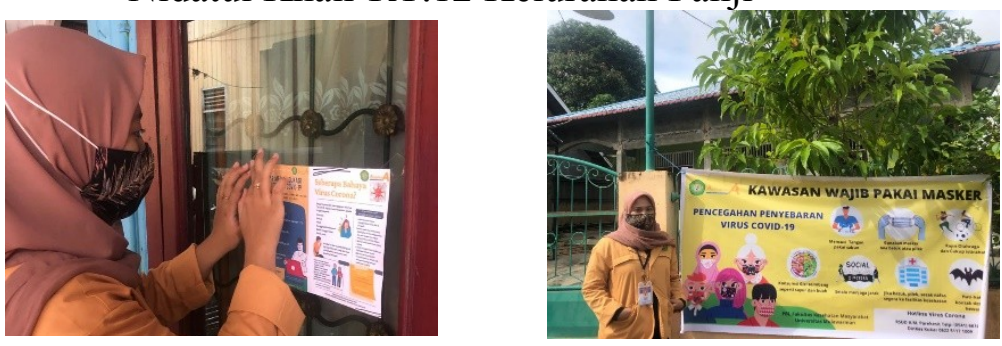

\section{KESIMPULAN}

Berdasarkan hasil pelaksanaan kegiatan yang telah dilakukan, dapat ditarik beberapa kesimpulan sebagai berikut;

1. Kegiatan pembagian poster dan pemasangan spanduk di wilayah Gang Nidatul Khair RT.12 Kelurahan Panji berjalan dengan lancar dan tanpa ada hambatan. 
2. Kegiatan ini dirasakan sangat bermanfaat karena dapat menambah pengetahuan serta meningkatkan kesadaran masyarakat tentang bahaya dan pentingnya pencegahan Covid-19 serta akses informasi kesehatan.

3. Setelah dilaksanakanannya kegiatan pemasangan spanduk dan pembagian poster di wilayah Gang Nidatul Khair RT.12 Kelurahan Panji, masyarakat sudah mulai sadar tentang bahaya dan pentingnya pencegahan Covid-19 serta akses informasi kesehatan.

4. Kegiatan pengalaman belajar lapangan (PBL) yang dilakukan oleh mahasiswa Fakultas Kesehatan Masyarakat Universitas Mulawarman merupakan sebuah kegiatan positif yang bertujuan menghimbau seluruh masyarakat untuk melawan Covid-19.

\section{E. UCAPAN TERIMA KASIH}

Pada situasi dan kondisi saat ini, kesadaran seluruh masyarakat untuk patuh dan taat dalam menjalankan protokol kesehatan memiliki peranan yang signifikan, sehingga perlu ditekankan kepada seluruh masyarakat untuk selalu mematuhi protokol Covid-19 agar mengurangi dan memutus rantai penyebaran virus corona.

Terima kasih kepada Dekan Fakultas Kesehatan Masyarakat Universitas Mulawarman, dosen pembimbing PBL, Ketua RT.12 Kelurahan Panji, serta seluruh warga Gang Nidatul Khair RT.12 Kelurahan Panji 


\section{DAFTAR PUSTAKA}

Dinas Kesehatan Kabupaten Kutai Kartanegara (2020) 'Update 17 Desember: Bertambah 39 Kasus Positif, kini Total Kasus Covid-19 Kukar jadi 4.500 Kasus', dinkes.kukarkab.go.id. Available at: http://dinkes.kukarkab.go.id/baca-berita-432-update-17-desember-bertambah-39-kasus-positif-kini-total-kasus-covid19-kukar-jadi4500-kasus.html.

Mashudi, M., Suparyanto, D., \& Arisandi, B. (2020). Pendayagunaan Potensi Ekonomi Desa Paterongan Kecamatan Galis Melalui KKN Mahasiswa STAIDHI Tahun 2020. Dharma: Jurnal Pengabdian Masyarakat, 1(1), 1-16

Kementrian Kesehatan (2020) 'Novel Coronavirus'. Available at: https://www.kemkes.go.id/folder/view/full-content/structurefaq.html.

Kompas (2020) 'Update Kasus Covid-19 17 Desember 2020’, Kompas.com. Available at: https://nasional.kompas.com/read/2020/12/17/16000551/updatebertambah-7354-kini-ada-643508-kasus-covid-19-di-indonesia? page $=$ all.

Ratnawati, R. et al. (2021) 'Penyuluhan Tentang Covid-19 Dengan Pemanfaatan Media Poster Pada Masyarakat Di Desa Mangunrejo', Jurnal Pengabdian Dharma Bakti, 1(1), p. 56. doi: 10.35842/jpdb.v1i1.140.

WHO (2020) 'WHO announces COVID-19 outbreak a pandemic' World Health Organzation Regional Office for Europe'. Available at: http://www.who.int/en/healthtopics/health\%0Aemergencies/corona virus-covid19/news/news/2020/3/whoannouncescovid-19outbreak-a-pandemic . 